\title{
Fish use of subtropical saltmarshes in Queensland, Australia: relationships with vegetation, water depth and distance onto the marsh
}

\author{
Bonnie E. Thomas, Rod M. Connolly* \\ School of Environmental \& Applied Sciences, Gold Coast campus, Griffith University, PMB 50, Gold Coast Mail Centre, \\ Queensland 9726, Australia
}

\begin{abstract}
Saltmarshes in subtropical Queensland, Australia, are assumed to provide habitat for fish, yet there has been no evidence as to whether fish actually occur on the intertidal flats that constitute the main area of marshes. Nor has there been any assessment of differences in fish use of vegetated habitat and the extensive unvegetated saltpans that occur naturally and because of human activities. Fish were sampled from the intertidal flats of 2 saltmarshes in subtropical Queensland using floorless, buoyant pop nets $\left(25 \mathrm{~m}^{2}\right)$ on sets of spring high tides in summer (during day) and winter (at night). A total of 23 species was collected, with densities ranging up to 0.46 fish $\mathrm{m}^{-2}$. Catches were dominated numerically by small, estuarine-resident species such as glassfish (Ambassidae) and gobies (Gobiidae). Economically important species such as bream (Sparidae), whiting (Sillaginidae) and mullet (Mugilidae) also contributed substantially (up to 92\%) to the catch. Fish assemblages were compared in adjacent patches of intertidal vegetated and unvegetated habitat, at distances varying from 3 to $413 \mathrm{~m}$ onto the marsh. Fish densities were highly variable among patches on a marsh, and also varied between sampling periods and between marshes. Species richness and the densities of common species differed little between vegetated and unvegetated habitats. Two species, Mugilogobius stigmaticus and Atherinomorus ogilbyi, had higher densities in vegetated habitat, but only at 1 sampling time and marsh. Fish occurred at all distances onto the marsh. Species richness and the densities of some species were positively related to water depth and negatively related to distance onto the marsh at one, but not the other marsh. This study provides the first evidence that, despite the relatively low duration and frequency of inundation of marshes, there is widespread use by fish of intertidal saltmarsh flats in Australia.
\end{abstract}

KEY WORDS: Coastal wetland · Fisheries - Submerged aquatic vegetation (SAV) • Estuary · Sporobolus $\cdot$ Gobiidae

Resale or republication not permitted without written consent of the publisher

\section{INTRODUCTION}

Aquatic habitats associated with saltmarshes can support very high densities of larvae and juveniles of estuarine fish species (Weinstein 1979, Boesch \& Turner 1984, Talbot \& Able 1984, Kneib 1997). Around $90 \%$ of studies that have sampled fish on saltmarshes are from North America (Connolly 1999), but results from those studies might not represent fish use of Aus-

*Corresponding author. E-mail: r.connolly@mailbox.gu.edu.au tralian saltmarshes. Saltmarshes in Australia typically occur landward of mangrove forests, high in the intertidal zone, and have considerably shorter and less frequent periods of inundation than northern hemisphere saltmarshes, which generally lack mangroves and extend down to the mid-intertidal zone. The vegetation of Australian saltmarshes is dominated by short succulent bushes (family Chenopodiaceae) and saltcouch grass Sporobolus virginicus, which are considerably shorter than the stands of cordgrass Spartina spp. dominating northern hemisphere saltmarshes (Adam 1990). 
Studies of the fish assemblages of Australian saltmarshes are scarce. Initial work in Australia was done in single tidal creeks that drained the saltmarsh flats (Gibbs 1986, Morton et al. 1987, Davis 1988), and in semi-permanent pools that remain on the flats after the tide has receded (Gibbs 1986, Davis 1988, Morton et al. 1988). None of these studies, however, investigated whether fish actually occurred on the intertidal saltmarsh flats. These flats constitute, by area, the main saltmarsh habitat. Connolly et al. (1997) were the first to sample fish on intertidal saltmarsh flats in Australia. They caught 2 species (the small-mouthed hardyhead Atherinosoma microstoma and the glass goby Gobiopterus semivestitus) at very low densities on a temperate marsh flat in South Australia.

Saltmarshes in subtropical and tropical Australian waters have extensive unvegetated areas or saltpans interspersed among vegetated areas. Furthermore, although saltmarshes are protected in most places from destruction, vegetation is being damaged or removed by anthropogenic activities such as cattle grazing, use of off-road vehicles and changing drainage regimes to control pest insect populations. It is therefore important to account for differences between vegetated and unvegetated habitat when determining fish use of Australian saltmarshes. Only a few studies have tested for differences in fish assemblages between vegetated and unvegetated marsh habitat (Zimmerman \& Minello 1984, Zimmerman et al. 1984), and different vegetation types (Rozas \& Reed 1993), and these have all been on the Gulf of Mexico coast of the USA, where tides are small and wind-driven and the marsh can be submerged for days at a time. Nekton densities were directly compared between vegetated (Spartina alterniflora) and unvegetated habitats in a Texas saltmarsh (Zimmerman \& Minello 1984). Of the 29 species of fish, 14 species had at least $75 \%$ of their total abundance in vegetated habitat, 10 species were more abundant in unvegetated habitat and 5 had similar abundances in both habitats. Densities of grass shrimp Palaemonetes pugio, brown shrimp Farfantepenaeus aztecus and white shrimp Litopenaeus setiferus were consistently greater in vegetated habitat (Minello 1998). No comparisons have been made of fish use of vegetated and unvegetated intertidal habitat on the Atlantic coast of the USA, where tidal ranges are more similar to those in subtropical Australia.

Saltmarsh flats often extend considerable distances, up to kilometres from subtidal water, but are rarely sampled beyond the seaward edge $(10 \mathrm{~m})$. Peterson \& Turner (1994) sampled nekton at 4 distances from a creek edge in Louisiana, ranging from 3 to $40 \mathrm{~m}$, as well as in the adjacent creek. They found the saltmarsh flat was used primarily by decapod crustaceans and marsh-resident fish (e.g. Fundulus pulvereus). Marine species (e.g. Cynoscion nebulosus) sometimes ventured onto the marsh flat, but spent more time in adjacent subtidal creeks. Kneib \& Wagner (1994) sampled at 2 distances (25 and $90 \mathrm{~m}$ ) from the seaward edge of a saltmarsh in Georgia. Few species, but substantial numbers of nekton, regularly occurred at $90 \mathrm{~m}$ onto the marsh. Kneib \& Wagner (1994) also showed that for the particular species that did venture onto the marsh flat, larger fish moved farther onto the marsh than smaller fish. This was attributed to larger fish having a smaller risk of becoming stranded on the outgoing tide, because of their greater swimming capabilities (Kneib \& Wagner 1994).

In the present study, fish were sampled in summer (when the marsh is inundated during the day) and in winter (when inundation is at night), on 2 subtropical saltmarshes in southeast Queensland, from areas of the marsh flats that were submerged at high tide and emergent at low tide. The aim of the study was to determine what fish species, in what abundance, occur on these marsh flats. Fish from vegetated and unvegetated (saltpan) habitats were compared for differences in species richness and density. Size distributions of the dominant species were also compared for differences between the 2 habitats. Lastly, we attempted to relate species richness and fish density to distance onto the marsh and water depth.

\section{METHODS}

Study sites and timing of sampling. Fish were sampled on 2 subtropical saltmarshes in southeast Queensland, at Meldale in northern Moreton Bay $\left(27^{\circ} 5^{\prime} \mathrm{S}\right.$, $\left.153^{\circ} 9^{\prime} \mathrm{E}\right)$ and Theodolite Creek in Hervey Bay $\left(25^{\circ} 10^{\prime} \mathrm{S}\right.$, $152^{\circ} 25^{\prime} \mathrm{E}$ ) (Fig. 1). The 2 marshes were chosen because they are not grazed by cattle, have relatively easy access for sampling, and are far apart $(250 \mathrm{~km})$. Tidal flows at Meldale occur through a large creek which drains into Pumicestone Passage, an estuarine component of Moreton Bay. The Theodolite marsh is associated with a much smaller estuary, consisting of one shallow creek adjacent to the marsh and another creek that drains directly into Hervey Bay. Meldale is $15 \mathrm{~km}$ and Theodolite $2 \mathrm{~km}$ from open waters.

A short turf of beaded glasswort Sarcocornia quinqueflora and patches of saltcouch grass Sporobolus virginicus dominated the vegetation at Meldale. A succulent bush, Halosarcia sp., dominated the vegetation at Theodolite. Single mangrove trees of Avicennia marina and Rhyzophora stylosa occurred on both marshes. Both marshes consist mainly of vegetated and unvegetated intertidal flats, with occasional semi-permanent pools and mangrove-lined feeder creeks. The Meldale marsh comprises, by area, 62\% vegetated 
areas, $24 \%$ unvegetated areas and $14 \%$ creeks/ drainage channels, whereas Theodolite has 60, 19 and $21 \%$, respectively. Sizes of vegetated and unvegetated patches sampled at each marsh ranged from 0.02 to 1.7 ha and 0.003 to 1.0 ha, respectively.

Tides within the study area are semi-diurnal, with amplitudes ranging up to $2.1 \mathrm{~m}$ (Meldale) and $3.1 \mathrm{~m}$ (Theodolite). Marshes are completely inundated for approximately 4 consecutive days on the highest of spring high tides. During these periods they are completely inundated for an average of $17 \%$ of the time, and are partially inundated for much longer. On a yearly basis, the percentage of time subtropical Queensland marshes are completely submerged is approximately $1 \%$, with strong seasonality; marshes are not completely inundated during autumn and spring, but are submerged for $3 \%$ of the summer and winter periods (Connolly 1999).

The present study consisted of 2 sampling periods at each marsh, one in winter (Meldale, June 1997; Theodolite, August 1997) during nighttime high tides (full moon phase) and the other in summer (Meldale, January 1998; Theodolite, March 1998) during daytime high tides (new moon phase). For each sampling period, the number of sampling days was determined by the number of high tides that completely inundated the marsh. For both the winter and summer sampling periods, the Meldale marsh was sampled for 4 consecutive days and Theodolite was sampled for 3 consecutive days.

Fish collections. The spatial extent of inundation at each marsh was estimated by inspecting vegetation type and observing inundation events prior to the study. This area of inundation was designated as the study area within which fish were sampled. Fish were captured using a series of floorless, buoyant pop nets, modified from Connolly (1994). Nets consisted of 4 walls of $1 \mathrm{~mm}$ diameter mesh (5 m long $\times 1 \mathrm{~m}$ high), which, when installed, form a square sitting flush with the marsh surface. Disturbance to the marsh surface is minimised by compressing the substrate to form a shallow depression rather than digging a trench for the net. The time required for 2 people to install a net was 90 min (including the time to disassemble a net and transport it to the next sampling site). At slack high tide, the nets were released, surfacing within $2 \mathrm{~s}$ of deployment and enclosing an area of $25 \mathrm{~m}^{2}$. Nets were positioned so that fish would be channelled towards one corner as the tide retreated. To mitigate against predation by scavengers once nets were released, nets were revisited frequently as the tide receded and fish were collected with hand-held dip nets from the downstream corner where they congregated. A final visual inspection of enclosed areas was made once the area had drained, as species of Gobiidae occasionally remained in tiny depressions, becoming camouflaged by

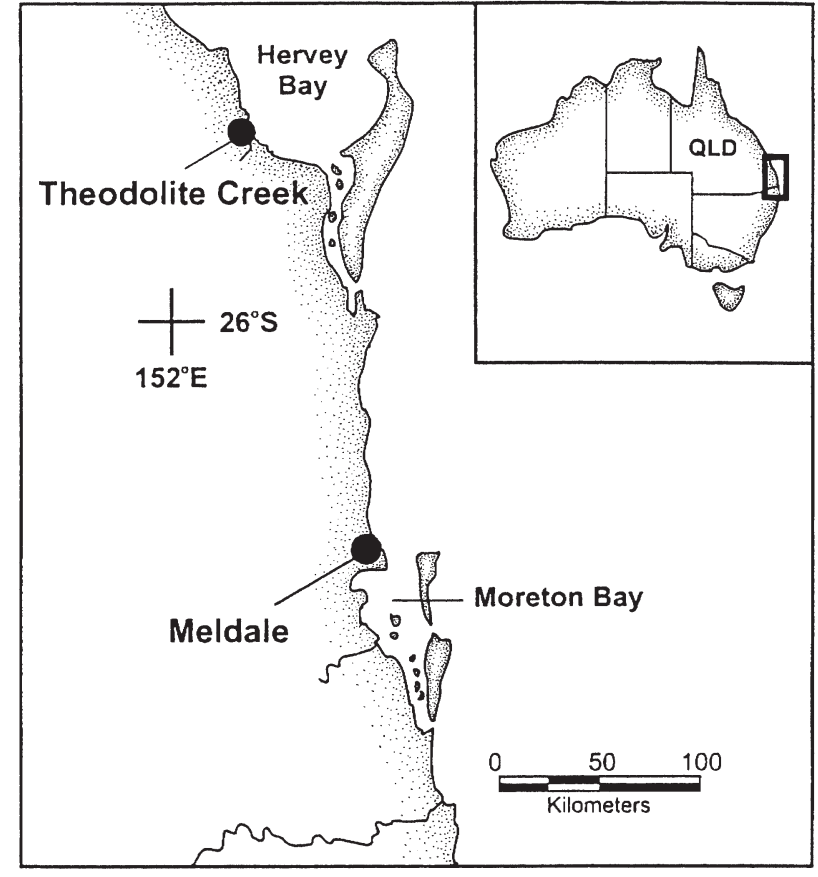

Fig. 1. The 2 marsh locations sampled during the study

the mud surface. All fish were identified, counted and measured to the nearest millimetre using total length (TL).

Comparisons of fish assemblages in vegetated and unvegetated habitat were made using a paired sampling design. This design limits the influence of factors that were not investigated in the present study (e.g. proximity to mangroves and day of release), but that may have confounded the comparison of vegetated and unvegetated habitat. Vegetated and unvegetated patches were sampled by placing a pair of nets at each site, 1 in each habitat, no further than $25 \mathrm{~m}$ apart. Sites were selected so as to represent the inundated marsh flats (covering approximately 16 ha at Meldale and 15 ha at Theodolite) and to sample at several distances onto the marsh where both habitats occurred. Placement of nets at sites, within habitat patches, was done randomly but with compliance to the $25 \mathrm{~m}$ maximum separation criterion. The centre of patches with a radius $>25 \mathrm{~m}$ therefore could not be sampled. An approximately equal number of sites were chosen in each of 3 strata ranging from alongside subtidal water to the terrestrial edge of the marsh (413 $\mathrm{m}$ from subtidal water at Meldale, $201 \mathrm{~m}$ at Theodolite). These distance strata were used purely to ensure sites were placed at a range of distances onto the marsh and were not used as a treatment in data analysis. In summer, the Meldale marsh was only sampled up to $320 \mathrm{~m}$, because tidal heights were lower than predicted during this period. Nets were moved to new sites after 
each collection day. The actual day on which a particular site was sampled was chosen so that a broad spread of sites was achieved each day. A total of 14 paired samples was taken at each sampling period at Meldale; 18 paired samples were taken at Theodolite in winter and 21 pairs in summer.

Distance onto the marsh was measured as distance from sites to the nearest seaward edge of the marsh. Habitat patches show clearly on aerial photos, and, within a patch, sites were lined up in the field with prominent landscape features in 2 directions. Distances were obtained by ground-truthing the scale on an aerial photo, and then locating the sites on the aerial photo and measuring the distances between the sites and the seaward edge of the marsh. Water depth $( \pm 1 \mathrm{~cm})$ at each net, and water temperature $\left( \pm 1^{\circ} \mathrm{C}\right)$ and salinity $( \pm 0.5 \%)$ at each paired site were measured after both nets in each pair were released (Table 1). Average plant height in vegetated plots is also shown in Table 1.

Data analysis. Differences in fish assemblages between the 2 sampling periods and between vegetated and unvegetated habitat were displayed for each marsh separately using non-metric multidimensional scaling (NMDS). Stress is a measure of how well the solution represents the distances between data. Clarke (1993) suggests values $<0.01$ are good and $<0.2$ are useful. Multivariate differences were tested for significance using analysis of similarities (ANOSIM) (Clarke 1993). Raw counts were transformed using $x^{0.25}$ to emphasise the distribution of less-common species in the analysis, and the Bray-Curtis similarity coefficient was used throughout.

For univariate analyses each sampling event was treated separately because: (1) the 2 marshes were sampled in different months, and (2) multivariate analyses showed that assemblages differed between winter and summer periods. Wilcoxon's paired-sample test was used to determine any differences between vegetated and unvegetated habitats in the variables listed below. This non-parametric test was used because the paired data typically did not have normally distributed differences. The ranking of the differences involved in this test also prevents the often large differences obtained for schooling species from obscuring patterns in nonschooling species. The variables analysed were species richness (number of species sample ${ }^{-1}$ ) and the density (fish $\mathrm{m}^{-2}$ ) of: (1) all species combined, (2) all species excluding the dominant species, (3) the dominant species alone, and (4) selected other species considered common enough to analyse (occurring in $\geq 4$ nets). Analysis of density with the exclusion of the dominant species was not done for Theodolite in winter, because the number of fish was too low to make useful comparisons between the 2 habitats. Lengthfrequency distributions were compared between vegetated and unvegetated habitat using KolmogorovSmirnov tests for species with at least 10 individuals in each habitat for any sampling period.

Multiple regressions were used to test for relationships between 2 independent variables (distance onto the marsh and water depth) and the dependent variables species richness and fish density. The aim was to determine whether either of the independent variables alone or the two in combination were good predictors of species richness or fish density. Vegetated and unvegetated habitats were analysed separately in case fish assemblages were influenced by depth and distance differently in each habitat. Regressions were done on $\log (x+1)$ transformed data, as this transformation made the residuals more even when plotted against the independent variables. The density variables analysed were: (1) all species combined, (2) exclusion of dominant species, and (3) individual species that occurred in at least 4 nets in a particular habitat.

\section{RESULTS}

\section{Species composition}

From 56 pop nets released at Meldale, 396 fish of 15 species from 9 families were caught, with $55 \%$ of nets catching fish. From 78 nets released at Theodolite, 181 fish of 21 species from 13 families were caught, with $50 \%$ of nets catching fish. Different species were

Table 1. Physico-chemical characteristics at each marsh for each sampling period. Salinity and temperature entries are means (SE). Vegetation heights are the range of averages at vegetated plots. N: number of paired-samples

\begin{tabular}{|c|c|c|c|c|c|c|c|}
\hline Location & Season & \multicolumn{2}{|c|}{ Depth range $(\mathrm{cm})$} & $\mathrm{N}$ & $\begin{array}{l}\text { Height of vegetation } \\
\text { (range, } \mathrm{cm})\end{array}$ & $\begin{array}{l}\text { Salinity } \\
(\% \circ)\end{array}$ & $\begin{array}{c}\text { Temperature } \\
\left({ }^{\circ} \mathrm{C}\right)\end{array}$ \\
\hline \multirow[t]{2}{*}{ Meldale } & Winter & $4-28$ & $5-43$ & 14 & $5-18$ & $16(0.4)$ & $16(0.1)$ \\
\hline & Summer & $4-19$ & $6-22$ & 14 & $6-15$ & $27(0.7)$ & $33(0.6)$ \\
\hline \multirow[t]{2}{*}{ Theodolite } & Winter & $7-63$ & $11-56$ & 18 & $3-16$ & $28(2.0)$ & $19(0.2)$ \\
\hline & Summer & $19-72$ & $28-70$ & 21 & $5-13$ & $30(0.8)$ & $27(0.3)$ \\
\hline
\end{tabular}


numerically dominant at the 2 marsh sites, and these were commonly associated with estuarine waters. Ambassis marianus and Gobiopterus semivestitus numerically dominated the winter catch at Meldale, representing 50 and $31 \%$ of the catch, respectively. For the summer sampling period, A. marianus (41\%) and Tetractenos hamiltoni (12\%) were numerically dominant (Table 2). At Theodolite in winter, the catch was dominated by Acanthopagrus australis (24\%), with A. marianus and Mugilogobius stigmaticus also con- tributing $19 \%$ each to the total catch. In summer, Atherinomorus ogilbyi dominated, representing $74 \%$ of the catch (Table 3 ). With the exception of A. australis, these species were present as juveniles and adults. Ordination plots showed separation of winter and summer samples at both marshes (Fig. 2a, only Meldale shown), and these differences were significant (ANOSIM: $p<0.001$ for both marshes). Of the 23 species caught, 14 are of economic importance, in recreational and/or commercial fisheries. These ex-

Table 2. Summary of species richness and mean fish densities at Meldale in vegetated and unvegetated habitats for winter (W) and summer (S). Uncommon species are not listed (see 'Results'). Overall: habitats combined; \% total: \% of total fish abundance at that season. ${ }^{*}$ Economic species; E: solely estuarine species; ME: species in marine and estuarine waters

\begin{tabular}{|c|c|c|c|c|c|c|}
\hline $\begin{array}{l}\text { Species } \\
\text { common name }\end{array}$ & Habitat & Season & Overall & $\%$ total & Vegetated & Unvegetated \\
\hline $\begin{array}{l}\text { Species richness } \\
\left(\text { no. of species sample }^{-1} \text { ) }\right.\end{array}$ & & $\begin{array}{l}\mathrm{W} \\
\mathrm{S}\end{array}$ & & & $\begin{array}{l}2.143 \\
0.571\end{array}$ & $\begin{array}{l}1.786 \\
1.071\end{array}$ \\
\hline \multicolumn{7}{|l|}{$\begin{array}{l}\text { Density } \\
\text { (fish } \mathrm{m}^{-2} \text { ) }\end{array}$} \\
\hline $\begin{array}{l}\text { Acanthopagrus australis }{ }^{*} \\
\text { Yellowfin bream }\end{array}$ & $\mathrm{ME}$ & $\begin{array}{l}\mathrm{W} \\
\mathrm{S}\end{array}$ & $\begin{array}{l}0.007 \\
0.003\end{array}$ & $\begin{array}{l}2 \\
3\end{array}$ & 0.006 & $\begin{array}{l}0.009 \\
0.006\end{array}$ \\
\hline $\begin{array}{l}\text { Ambassis marianus } \\
\text { Ramsay's glassfish }\end{array}$ & $\mathrm{E}$ & $\begin{array}{l}\mathrm{W} \\
\mathrm{S}\end{array}$ & $\begin{array}{l}0.233 \\
0.046\end{array}$ & $\begin{array}{l}50 \\
41\end{array}$ & 0.323 & $\begin{array}{l}0.143 \\
0.091\end{array}$ \\
\hline $\begin{array}{l}\text { Arrhamphus sclerolepis * } \\
\text { Snub-nosed garfish }\end{array}$ & $\mathrm{ME}$ & $\begin{array}{l}\mathrm{W} \\
\mathrm{S}\end{array}$ & $\begin{array}{l}0.003 \\
0.004\end{array}$ & $\begin{array}{l}1 \\
4\end{array}$ & & $\begin{array}{l}0.006 \\
0.009\end{array}$ \\
\hline $\begin{array}{l}\text { Atherinomorus ogilbyi* } \\
\text { Ogilby's hardyhead }\end{array}$ & $\mathrm{E}$ & $\begin{array}{l}\mathrm{W} \\
\mathrm{S}\end{array}$ & 0.006 & 5 & & 0.011 \\
\hline $\begin{array}{l}\text { Gerres subfasciatus }{ }^{*} \\
\text { Black-tipped silver belly }\end{array}$ & $\mathrm{ME}$ & $\begin{array}{l}\mathrm{W} \\
\mathrm{S}\end{array}$ & $\begin{array}{l}0.004 \\
0.010\end{array}$ & $\begin{array}{l}1 \\
9\end{array}$ & & $\begin{array}{l}0.009 \\
0.020\end{array}$ \\
\hline $\begin{array}{l}\text { Gobiopterus semivestitus } \\
\text { Glass goby }\end{array}$ & $\mathrm{E}$ & $\begin{array}{l}\mathrm{W} \\
\mathrm{S}\end{array}$ & $\begin{array}{l}0.144 \\
0.007\end{array}$ & $\begin{array}{r}31 \\
6\end{array}$ & 0.171 & $\begin{array}{l}0.117 \\
0.014\end{array}$ \\
\hline $\begin{array}{l}\text { Liza argentea } \\
\text { Tiger mullet }\end{array}$ & $\mathrm{ME}$ & $\begin{array}{l}\mathrm{W} \\
\mathrm{S}\end{array}$ & 0.003 & 1 & 0.003 & 0.003 \\
\hline $\begin{array}{l}\text { Marilyna pleurosticta } \\
\text { Banded toadfish }\end{array}$ & $\mathrm{E}$ & $\begin{array}{l}\mathrm{W} \\
\mathrm{S}\end{array}$ & 0.004 & 1 & 0.006 & 0.003 \\
\hline $\begin{array}{l}\text { Mugilogobius stigmaticus } \\
\text { Mangrove goby }\end{array}$ & $\mathrm{E}$ & $\begin{array}{l}\mathrm{W} \\
\mathrm{S}\end{array}$ & $\begin{array}{l}0.034 \\
0.009\end{array}$ & $\begin{array}{l}7 \\
8\end{array}$ & $\begin{array}{l}0.063 \\
0.006\end{array}$ & $\begin{array}{l}0.006 \\
0.011\end{array}$ \\
\hline Pseudogobius sp. & $\mathrm{E}$ & $\begin{array}{l}\mathrm{W} \\
\mathrm{S}\end{array}$ & $\begin{array}{l}0.003 \\
0.009\end{array}$ & $\begin{array}{l}1 \\
8\end{array}$ & 0.009 & $\begin{array}{l}0.006 \\
0.009\end{array}$ \\
\hline $\begin{array}{l}\text { Pseudomugil signifer } \\
\text { Pacific blue-eye }\end{array}$ & $\mathrm{E}$ & $\begin{array}{l}\mathrm{W} \\
\mathrm{S}\end{array}$ & 0.003 & 1 & & 0.006 \\
\hline $\begin{array}{l}\text { Sillago maculata* } \\
\text { Winter whiting }\end{array}$ & $\mathrm{ME}$ & $\begin{array}{l}\mathrm{W} \\
\mathrm{S}\end{array}$ & $\begin{array}{l}0.004 \\
0.006\end{array}$ & $\begin{array}{l}1 \\
5\end{array}$ & $\begin{array}{l}0.003 \\
0.003\end{array}$ & $\begin{array}{l}0.006 \\
0.009\end{array}$ \\
\hline $\begin{array}{l}\text { Tetractenos hamiltoni } \\
\text { Common toadfish }\end{array}$ & $\mathrm{E}$ & $\begin{array}{l}\mathrm{W} \\
\mathrm{S}\end{array}$ & $\begin{array}{l}0.009 \\
0.013\end{array}$ & $\begin{array}{r}2 \\
12\end{array}$ & $\begin{array}{l}0.011 \\
0.020\end{array}$ & $\begin{array}{l}0.006 \\
0.006\end{array}$ \\
\hline Total (all species) & & $\begin{array}{l}\mathrm{W} \\
\mathrm{S}\end{array}$ & $\begin{array}{l}0.455 \\
0.111\end{array}$ & & $\begin{array}{l}0.597 \\
0.037\end{array}$ & $\begin{array}{l}0.311 \\
0.186\end{array}$ \\
\hline $\begin{array}{l}\text { Dominant species } \\
\text { excluded }\end{array}$ & & $\begin{array}{l}\mathrm{W} \\
\mathrm{S}\end{array}$ & & & $\begin{array}{l}0.274 \\
0.037\end{array}$ & $\begin{array}{l}0.169 \\
0.094\end{array}$ \\
\hline
\end{tabular}



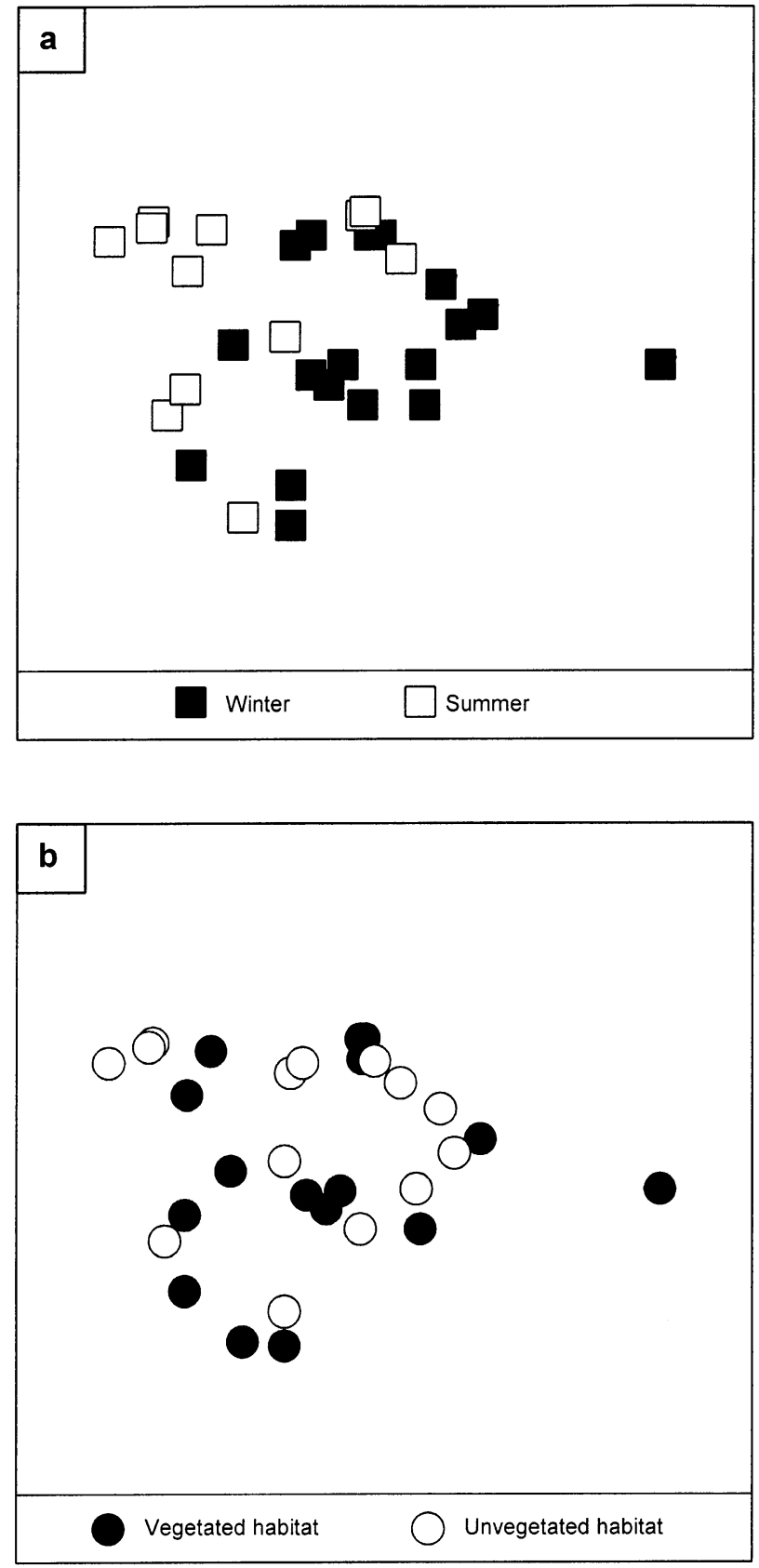

Fig. 2. Two-dimensional ordination (NMDS) plots of fish assemblages at Meldale marsh, stress 0.11, labelled to show: (a) winter/summer samples, and (b) vegetated/unvegetated sample. Samples in which no fish were caught are not shown

ploited species represented $34 \%$ of the total catch. All exploited species occurred as juveniles; species in the families Sparidae, Mugilidae and Hemirhamphidae also occurred as subadults. Species that were represented by only a single individual at a sampling period were omitted from Tables $2 \& 3$. These included Ambassis jacksoniensis and A. ogilbyi from winter samples at Meldale, Acentrogobius viridipunctatus, Myxus elongatus and Marilyna pleurosticta from winter samples at Theodolite, and Herklotsichthys castelnaui, Pseudogobius sp., Scomberoides lysan, Sillago maculata and T. hamiltoni from summer samples at Theodolite.

\section{Comparison of fish from vegetated and unvegetated habitats}

Ordination plots did not show clear separation of vegetated and unvegetated samples at either marsh (Fig. 2b, only Meldale shown), nor were samples from the 2 habitats significantly different (ANOSIM: $\mathrm{p}>0.05$ for both marshes). No significant difference in mean species richness (sample ${ }^{-1}$ ) was demonstrated between vegetated and unvegetated habitats for any of the 4 sampling periods (see Table 4 for the Wilcoxon results and Tables $2 \& 3$ for the means in each habitat).

At Meldale, the highest mean $( \pm \mathrm{SE})$ fish density was 0.60 fish $\mathrm{m}^{-2}( \pm 8.14, \mathrm{n}=14)$ which was recorded in vegetated habitat in winter, and the lowest $(0.04 \pm 0.40$, $\mathrm{n}=14$ ) was recorded in vegetated habitat in summer (Table 2). At Theodolite the highest density (0.24 \pm $2.82, \mathrm{n}=21$ ) was recorded in vegetated habitat in summer and the lowest $(0.02 \pm 0.87, \mathrm{n}=18)$ was in unvegetated habitat in winter (Table 3 ). Over all 4 sampling periods, significant differences in fish density between vegetated and unvegetated habitats were detected for just 2 variables (Table 4). At Meldale in winter, the density of Mugilogobius stigmaticus was significantly higher in vegetated habitat, as was Atherinomorus ogilbyi at Theodolite in summer (see Table 4 for the Wilcoxon results and Tables $2 \& 3$ for the means in each habitat). Of the pairs of nets where fish were caught in at least 1 habitat, $M$. stigmaticus had 5 pairs with the higher density in vegetated habitat and 0 pairs with higher density in unvegetated habitat. For A. ogilbyi, 8 pairs had the higher density in vegetated habitat, and 2 pairs with higher density in unvegetated habitat.

Given the small number of Wilcoxon tests that were significant, it is worthwhile examining the power of those tests. The power of a Wilcoxon test is approximately $95 \%$ of the power in an equivalent paired-sample $t$-test (Zar 1999). Since power cannot be calculated directly for Wilcoxon tests, power was estimated as $95 \%$ of the power of the equivalent paired-sample $t$-tests. For the paired $t$-test, the effect size is specified as the magnitude of the mean difference. We chose to consider a meaningful difference between habitats to be $\geq 50 \%$ of the overall mean within a given sampling period and marsh. For example, the overall mean density (all species) at Meldale in winter was $0.46 \mathrm{fish}^{-2}$. Therefore, the critical effect size was 0.23 fish $\mathrm{m}^{-2}$ (i.e. 
$50 \%$ of the overall mean). The chance of detecting a difference in density between habitat types at Meldale in winter with the effect size specified above was 0.10 $(\beta=0.90)$. Power of the Wilcoxon test comparing fish density amongst habitat types ranged from 0.07 to 0.37 (Table 4). The power of the Wilcoxon tests comparing species richness amongst habitat types ranged from 0.10 to 0.45 (Table 4 ). The low power of these tests may partly explain the lack of significant differences shown between vegetated and unvegetated habitats.

Tests of the relationship between fish density and habitat patch size (vegetated or unvegetated) using a Spearman's ranked correlation detected no significant associations at either period for either marsh (where a patch was sampled more than once, densities were averaged prior to testing; all tests, $\mathrm{p}>0.05$ ).

Table 3. Summary of species richness and mean fish densities at Theodolite in vegetated and unvegetated habitats for winter (W) and summer (S). Uncommon species are not listed (see 'Results'). Overall: habitats combined; \% total: \% of total fish abundance at that season. ${ }^{*}$ Economic species; E: solely estuarine species; ME: species in marine and estuarine waters

\begin{tabular}{|c|c|c|c|c|c|c|}
\hline $\begin{array}{l}\text { Species } \\
\text { common name }\end{array}$ & Habitat & Season & Overall & $\%$ total & Vegetated & Unvegetated \\
\hline $\begin{array}{l}\text { Species richness } \\
\left(\text { no. of species sample }{ }^{-1} \text { ) }\right.\end{array}$ & & $\begin{array}{l}\mathrm{W} \\
\mathrm{S}\end{array}$ & & & $\begin{array}{l}0.556 \\
1.000\end{array}$ & $\begin{array}{l}0.500 \\
0.762\end{array}$ \\
\hline \multicolumn{7}{|l|}{$\begin{array}{l}\text { Density } \\
\text { (fish } \mathrm{m}^{-2} \text { ) }\end{array}$} \\
\hline $\begin{array}{l}\text { Acanthopagrus australis * } \\
\text { Yellowfin bream }\end{array}$ & ME & $\begin{array}{l}\mathrm{W} \\
\mathrm{S}\end{array}$ & $\begin{array}{l}0.006 \\
0.005\end{array}$ & $\begin{array}{r}24 \\
3\end{array}$ & $\begin{array}{l}0.007 \\
0.008\end{array}$ & $\begin{array}{l}0.004 \\
0.002\end{array}$ \\
\hline $\begin{array}{l}\text { Ambassis marianus } \\
\text { Ramsay's glassfish }\end{array}$ & $\mathrm{E}$ & $\begin{array}{l}\mathrm{W} \\
\mathrm{S}\end{array}$ & $\begin{array}{l}0.004 \\
0.002\end{array}$ & $\begin{array}{r}19 \\
1\end{array}$ & 0.007 & $\begin{array}{l}0.002 \\
0.004\end{array}$ \\
\hline $\begin{array}{l}\text { Arrhamphus sclerolepis* } \\
\text { Snub-nosed garfish }\end{array}$ & ME & $\begin{array}{l}\mathrm{W} \\
\mathrm{S}\end{array}$ & 0.003 & 2 & 0.002 & 0.004 \\
\hline $\begin{array}{l}\text { Atherinomorus ogilbyi * } \\
\text { Ogilby's hardyhead }\end{array}$ & $\mathrm{E}$ & $\begin{array}{l}\mathrm{W} \\
\mathrm{S}\end{array}$ & 0.113 & 74 & 0.202 & 0.025 \\
\hline $\begin{array}{l}\text { Gerres subfasciatus }{ }^{*} \\
\text { Black-tipped silver belly }\end{array}$ & ME & $\begin{array}{l}\mathrm{W} \\
\mathrm{S}\end{array}$ & 0.009 & 6 & 0.011 & 0.006 \\
\hline $\begin{array}{l}\text { Gobiopterus semivestitus } \\
\text { Glass goby }\end{array}$ & $\mathrm{E}$ & $\begin{array}{l}\mathrm{W} \\
\mathrm{S}\end{array}$ & 0.005 & 3 & & 0.01 \\
\hline $\begin{array}{l}\text { Hyporhamphus quoyi* } \\
\text { Short-nosed garfish }\end{array}$ & $\mathrm{ME}$ & $\begin{array}{l}\mathrm{W} \\
\mathrm{S}\end{array}$ & 0.002 & 1 & & 0.004 \\
\hline $\begin{array}{l}\text { Liza argentea } \\
\text { Tiger mullet }\end{array}$ & $\mathrm{ME}$ & $\begin{array}{l}\mathrm{W} \\
\mathrm{S}\end{array}$ & 0.002 & 10 & 0.004 & \\
\hline $\begin{array}{l}\text { Mugil cephalus* } \\
\text { Sea mullet }\end{array}$ & ME & $\begin{array}{l}\mathrm{W} \\
\mathrm{S}\end{array}$ & 0.002 & 10 & & 0.004 \\
\hline $\begin{array}{l}\text { Mugilogobius stigmaticus } \\
\text { Mangrove goby }\end{array}$ & $\mathrm{E}$ & $\begin{array}{l}\mathrm{W} \\
\mathrm{S}\end{array}$ & 0.004 & 19 & 0.004 & 0.004 \\
\hline $\begin{array}{l}\text { Selenotoca multifasciata * } \\
\text { Striped butterfish }\end{array}$ & $\mathrm{E}$ & $\begin{array}{l}\mathrm{W} \\
\mathrm{S}\end{array}$ & 0.003 & 2 & & 0.006 \\
\hline $\begin{array}{l}\text { Terapon jarbua } \\
\text { Crescent perch }\end{array}$ & $\mathrm{E}$ & $\begin{array}{l}\mathrm{W} \\
\mathrm{S}\end{array}$ & 0.002 & 1 & & 0.004 \\
\hline $\begin{array}{l}\text { Tetractenos hamiltoni } \\
\text { Common toadfish }\end{array}$ & $\mathrm{E}$ & $\begin{array}{l}\mathrm{W} \\
\mathrm{S}\end{array}$ & 0.002 & 10 & & 0.004 \\
\hline $\begin{array}{l}\text { Valamugil georgii * } \\
\text { Fantail mullet }\end{array}$ & ME & $\begin{array}{l}\mathrm{W} \\
\mathrm{S}\end{array}$ & 0.004 & 3 & & 0.008 \\
\hline Total (all species) & & $\begin{array}{l}\mathrm{W} \\
\mathrm{S}\end{array}$ & $\begin{array}{l}0.023 \\
0.152\end{array}$ & & $\begin{array}{l}0.024 \\
0.238\end{array}$ & $\begin{array}{l}0.022 \\
0.067\end{array}$ \\
\hline $\begin{array}{l}\text { Dominant species } \\
\text { excluded }\end{array}$ & & $\begin{array}{l}\mathrm{W} \\
\mathrm{S}\end{array}$ & & & $\begin{array}{l}0.018 \\
0.036\end{array}$ & $\begin{array}{l}0.018 \\
0.042\end{array}$ \\
\hline
\end{tabular}



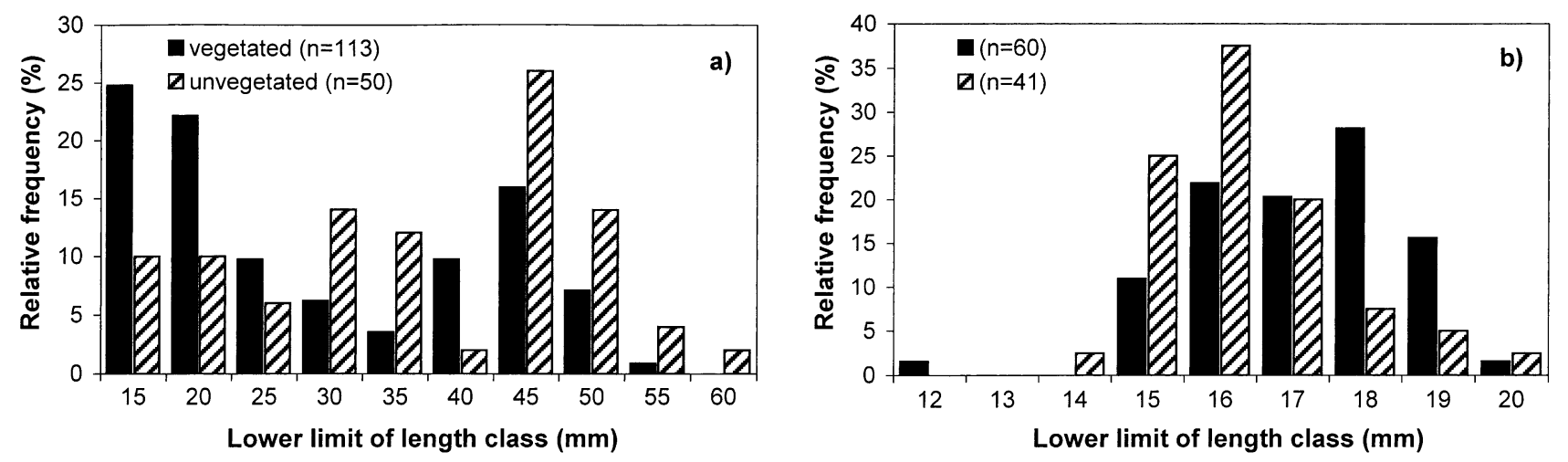

Fig. 3. Length-frequency distributions in vegetated and unvegetated habitats for (a) Ambassis marianus and (b) Gobiopterus semivestitus for the Meldale winter sampling period

Table 4. Results of Wilcoxon paired-sample test (given as probability, p) comparing species richness and density between vegetated and unvegetated habitats for the Meldale and Theodolite in winter (W) and summer (S) sampling periods. For mean paired differences between habitat types, catch in vegetated habitat is greater than unvegetated habitat, except where the difference is negative. Units for mean paired difference and effect size are given in parentheses under the variable types (d, dominant species)

\begin{tabular}{|c|c|c|c|c|c|c|}
\hline & Season & $\begin{array}{l}\text { Mean paired } \\
\text { difference }\end{array}$ & $\mathrm{p}$ & $\begin{array}{l}\text { Difference } \\
\text { as \% of veg. }\end{array}$ & $\begin{array}{l}\text { Effect } \\
\text { size }\end{array}$ & Power \\
\hline \multicolumn{7}{|l|}{ Meldale } \\
\hline Species richness & $\mathrm{W}$ & 0.3 & 0.467 & 14 & 1.0 & 0.45 \\
\hline (no. of species sample ${ }^{-1}$ ) & $\mathrm{S}$ & -0.5 & 0.558 & -83 & 0.4 & 0.10 \\
\hline \multicolumn{7}{|l|}{$\begin{array}{l}\text { Density } \\
\left(\text { fish } \mathrm{m}^{-2} \text { ) }\right.\end{array}$} \\
\hline \multirow[t]{2}{*}{ All species } & $\mathrm{W}$ & 0.286 & 0.213 & 48 & 0.228 & 0.10 \\
\hline & $\mathrm{S}$ & -0.149 & 0.389 & -403 & 0.056 & 0.07 \\
\hline \multirow[t]{2}{*}{ Dominant species excluded } & $\mathrm{W}$ & 0.105 & 0.332 & 38 & 0.111 & 0.16 \\
\hline & $\mathrm{S}$ & -0.057 & 0.389 & -154 & 0.033 & 0.09 \\
\hline \multirow[t]{2}{*}{ Mugilogobius stigmaticus } & $\mathrm{W}$ & 0.057 & $0.043^{*}$ & 68 & 0.017 & 0.09 \\
\hline & $\mathrm{S}$ & -0.005 & 0.705 & -83 & 0.005 & 0.07 \\
\hline Ambassis marianus (d) & $\mathrm{W}$ & 0.180 & 0.767 & 56 & 0.116 & 0.07 \\
\hline Acanthopagrus australis & $\mathrm{W}$ & -0.003 & 0.655 & -50 & 0.004 & 0.08 \\
\hline Gobiopterus semivestitus & $\mathrm{W}$ & 0.060 & 0.463 & 35 & 0.072 & 0.13 \\
\hline Tetractenos hamiltoni & $\mathrm{W}$ & 0.005 & 0.317 & 45 & 0.002 & 0.08 \\
\hline Pseudogobius sp. & $\mathrm{S}$ & 0 & 1.000 & 0 & 0.005 & 0.09 \\
\hline Sillago maculata & $\mathrm{S}$ & -0.006 & 0.317 & -200 & 0.003 & 0.08 \\
\hline \multicolumn{7}{|l|}{ Theodolite } \\
\hline Species richness & $\mathrm{W}$ & 0.1 & 0.272 & 17 & 0.3 & 0.14 \\
\hline (no. of species sample ${ }^{-1}$ ) & $\mathrm{S}$ & 0.2 & 0.675 & 20 & 0.4 & 0.39 \\
\hline \multicolumn{7}{|l|}{$\begin{array}{l}\text { Density } \\
\text { (fish } \mathrm{m}^{-2} \text { ) }\end{array}$} \\
\hline \multirow[t]{2}{*}{ All species } & $\mathrm{W}$ & 0.002 & 0.839 & 8 & 0.012 & 0.14 \\
\hline & $\mathrm{S}$ & 0.171 & 0.073 & 72 & 0.076 & 0.10 \\
\hline Dominant species excluded & $\mathrm{S}$ & -0.006 & 0.623 & -17 & 0.020 & 0.37 \\
\hline Acanthopagrus australis (d) & $\mathrm{W}$ & 0.003 & 0.705 & 43 & 0.003 & 0.08 \\
\hline Ambassis marianus & $\mathrm{W}$ & 0.005 & 0.317 & 71 & 0.002 & 0.07 \\
\hline Mugilogobius stigmaticus & $\mathrm{W}$ & 0 & 1.000 & 0 & 0.002 & 0.09 \\
\hline Atherinomorus ogilbyi (d) & $\mathrm{S}$ & 0.177 & $0.041^{*}$ & 88 & 0.057 & 0.07 \\
\hline${ }^{*} \mathrm{p}<0.05$ & & & & & & \\
\hline
\end{tabular}




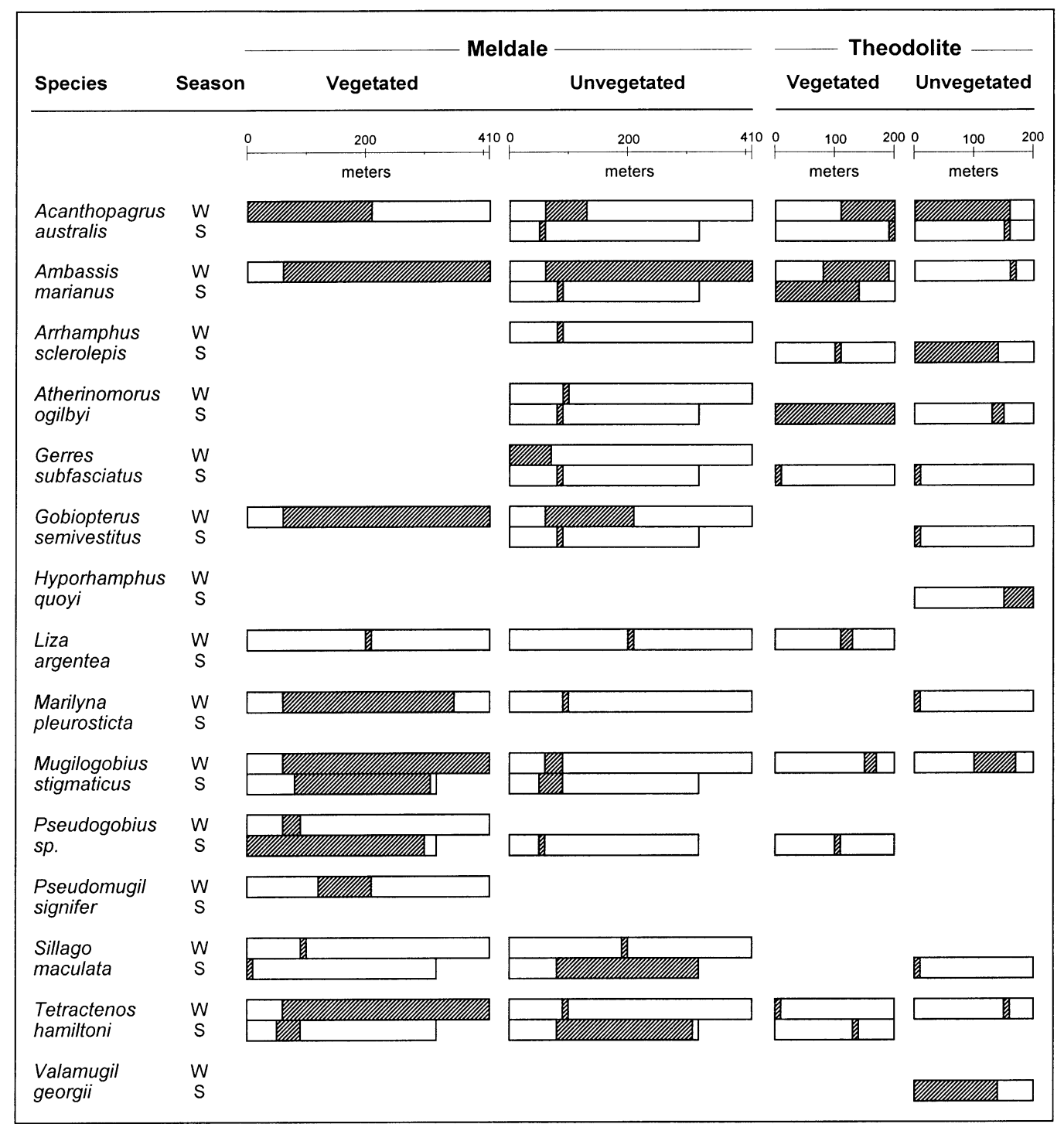

Fig. 4. Distances onto the marsh for each species caught. Hatched areas represent the distance range of each species caught, rounded to the nearest $10 \mathrm{~m}$. Species caught only in 1 net for the entire study are excluded (8 species). The ranges of distances sampled at Meldale were 3 to $413 \mathrm{~m}$ (winter) and 3 to $321 \mathrm{~m}$ (summer) and at Theodolite were 3 to $201 \mathrm{~m}$ (winter) and 3 to $195 \mathrm{~m}$ (summer)

There was evidence for habitat-specific differences in size distributions at Meldale in winter, when a greater proportion (KS test: $\mathrm{p}=0.003$ ) of juvenile Ambassis marianus was found in vegetated than unvegetated habitat (Fig. 3a). Size distributions of Gobiopterus semivestitus also differed significantly between habitat types (KS test: $\mathrm{p}=0.02$ ). In this case, more of the larger individuals (18 to $19 \mathrm{~mm}$ ) occurred in vegetated habitat (Fig. 3b). No difference was detected between the length-frequency distributions of Atherinomorus ogilbyi in vegetated and unvegetated habitats for the Theodolite summer sampling period ( $\mathrm{n}=106$ in vegetated, $\mathrm{n}=13$ in unvegetated, KS test: $\mathrm{p}=0.417$ ).

\section{Patterns in fish density with distance onto marsh and water depth}

Fish occurred even at the sites farthest from subtidal water, $413 \mathrm{~m}$ at Meldale and $201 \mathrm{~m}$ at Theodolite. Ambassis marianus, Mugilogobius stigmaticus and Tetractenos hamiltoni were widely distributed on the marsh flat at Meldale, in at least 1 habitat and 1 sampling period (Fig. 4). Several species did not occur in samples within the first $50 \mathrm{~m}$ of the seaward marsh edge, but were present in both habitats farther into the marsh interior at Meldale (Fig. 4). At Theodolite, Acanthopagrus australis was caught in vegetated sites farthest onto the marsh in both sampling periods (Fig. 4). 
Table 5. Summary of multiple regression analyses testing the influence of depth and distance on species richness and density in vegetated and unvegetated habitats at Meldale. Dependent variables that were not significant for at least 1 regression model were excluded ( 3 of these); $\mathrm{r}^{2}$ entries are adjusted for the number of variables. $\$$ : better predictor out of depth, distance and depthdistance combination

\begin{tabular}{|c|c|c|c|c|c|c|}
\hline \multirow{2}{*}{ Dependent variable } & \multirow{2}{*}{$\begin{array}{l}\text { Independent } \\
\text { variable }\end{array}$} & \multirow{2}{*}{ Season } & \multicolumn{2}{|c|}{ Vegetated } & \multicolumn{2}{|c|}{ Unvegetated } \\
\hline & & & $r^{2}$ & $\mathrm{p}$ & $\mathrm{r}^{2}$ & $\mathrm{p}$ \\
\hline \multirow[t]{3}{*}{ Species richness } & Depth-distance & W & 0.32 & $0.047^{*}$ & 0.58 & $0.004^{* *}$ \\
\hline & Depth & $\mathrm{W}$ & $>0.374$ & $0.012^{*}$ & $>0.614$ & $<0.001^{* * *}$ \\
\hline & Distance & W & 0.01 & 0.306 & 0.41 & $0.008^{* *}$ \\
\hline \multicolumn{7}{|l|}{ Density } \\
\hline \multirow[t]{6}{*}{ All species } & Depth-distance & W & 0.28 & 0.065 & 0.42 & $0.020^{*}$ \\
\hline & & $\mathrm{S}$ & 0.22 & 0.101 & & \\
\hline & Depth & $\mathrm{W}$ & $>0.324$ & $0.020^{*}$ & $\triangleright 0.474$ & $0.004^{* *}$ \\
\hline & & $\mathrm{S}$ & $>0.254$ & $0.038^{*}$ & & \\
\hline & Distance & W & 0.04 & 0.241 & 0.29 & $0.027^{*}$ \\
\hline & & $\mathrm{S}$ & 0.03 & 0.343 & & \\
\hline \multirow{3}{*}{$\begin{array}{l}\text { Dominant species } \\
\text { excluded }\end{array}$} & Depth-distance & $\mathrm{W}$ & 0.31 & 0.053 & $\triangleright 0.544$ & $<0.001^{* * *}$ \\
\hline & Depth & W & \0.334 & $0.018^{*}$ & 0.52 & $0.002^{* *}$ \\
\hline & Distance & W & 0.08 & 0.169 & 0.51 & $0.003^{* *}$ \\
\hline \multirow[t]{3}{*}{ Mugilogobius stigmaticus } & Depth-distance & $\mathrm{W}$ & 0.23 & 0.094 & & \\
\hline & Depth & W & $>0.294$ & $0.027^{*}$ & & \\
\hline & Distance & $\mathrm{W}$ & 0 & 0.381 & & \\
\hline \multirow[t]{3}{*}{ Gobiopterus semivestitus } & Depth-distance & $\mathrm{W}$ & 0.18 & 0.133 & & \\
\hline & Depth & W & 0.254 & $0.041^{*}$ & & \\
\hline & Distance & $\mathrm{W}$ & 0 & 0.404 & & \\
\hline \multirow[t]{3}{*}{ Tetractenos hamiltoni } & Depth-distance & W & 0.22 & 0.100 & & \\
\hline & Depth & W & $>0.294$ & $0.028^{*}$ & & \\
\hline & Distance & W & 0 & 0.440 & & \\
\hline
\end{tabular}

Within each sampling period at Theodolite, similar fish densities occurred at a range of distances onto the marsh. Neither species richness nor fish density showed a significant relationship with water depth or distance onto the marsh $(\mathrm{n}=18$ in each habitat in winter, $\mathrm{n}=21$ in each habitat in summer, $\mathrm{p}>0.05$ ) at this site. However, there were significant relationships between these variables at Meldale (Table 5). Since water depth can be related to distance onto the marsh, the influence of these 2 factors on fish density will not be independent, but it is of interest to determine which is the better predictor of species richness and fish densities. In winter Meldale samples, species richness was significantly related to water depth in both vegetated and unvegetated habitat, with more species coinciding with deeper water (Fig. 5a). Water depth on its own was found to be the better predictor of fish density in all but 1 case (Table 5). Six of the 8 significant relationships between density and water depth were in vegetated habitat, with all but 1 from the winter sampling period. Water depth was also the better predictor of total fish density in unvegetated habitat during the winter sampling period. In all cases, the relationship between density and water depth was positive as shown in Fig. 5b. When the dominant species (Ambassis marianus) was excluded from the analysis, the amount of variance explained by the depth-distance combination in unvegetated habitat was marginally higher than water depth or distance alone (Table 5). Density was positively related to depth and negatively related to distance onto the marsh (Fig. 5c,d). Although density in unvegetated habitat had fewer significant relationships than in vegetated habitat, on both occasions these relationships explained a higher amount of variance than any of the variables in vegetated habitat (Table 5).

For linear regression tests the effect size is specified as the correlation coefficient, $r$ (Zar 1999). We considered an r-value of 0.55 important to detect (i.e. coefficient of determination $\left[\mathrm{r}^{2}\right]=30 \%$ ). The power of the tests mentioned above was $0.57(\beta=0.43)$ when $\mathrm{n}=14$ (Meldale winter and summer), $0.69(\beta=0.31)$ when $\mathrm{n}=18$ (Theodolite winter) and $0.77(\beta=0.23)$ when $\mathrm{n}=21$ (Theodolite summer). 
a)

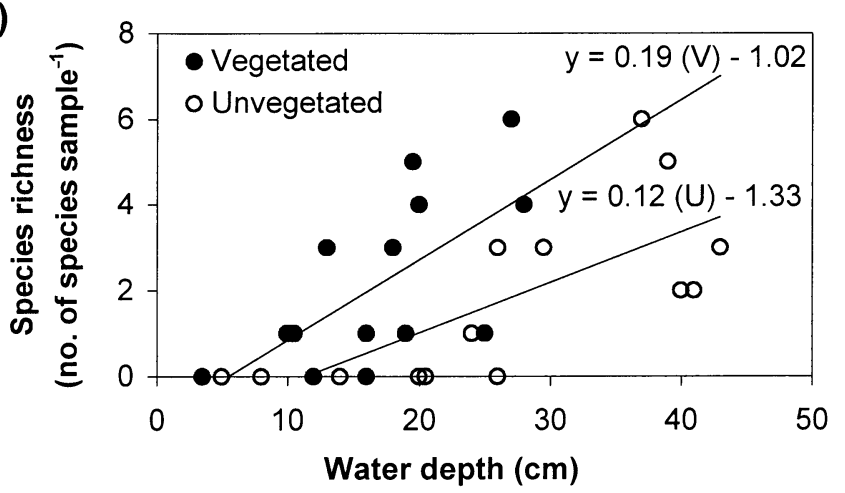

b)

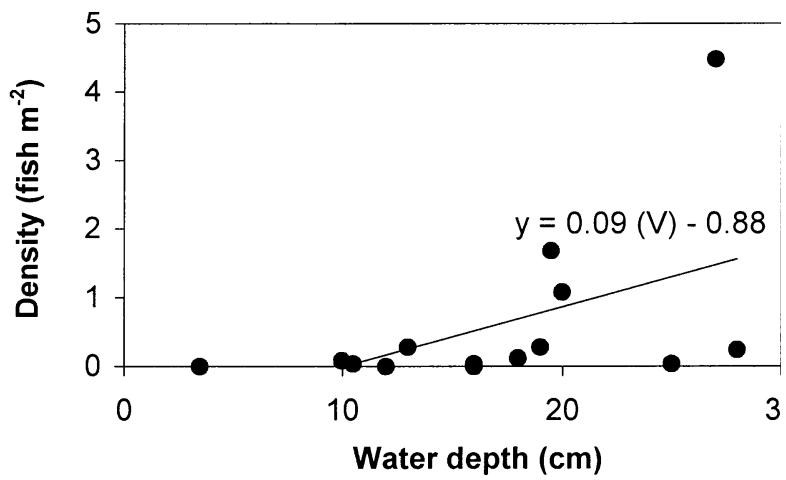

d)

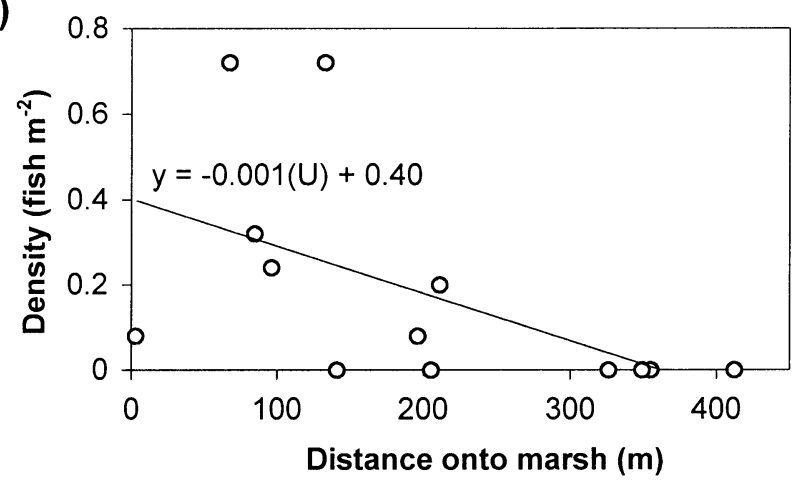

Fig. 5. Relationships between species richness and fish density with water depth and distance onto the marsh at Meldale in winter: (a) species richness in vegetated and unvegetated habitats with water depth; (b) total fish density in vegetated habitat with water depth; $(\mathrm{c}, \mathrm{d})$ density, excluding the dominant species, in unvegetated habitat with (c) water depth and (d) distance onto the marsh (V: vegetated; U: unvegetated)

\section{DISCUSSION}

Both marshes were dominated by estuarine species, with 2 species usually contributing between 50 and $80 \%$ to total abundance. These dominant species were from the families Ambassidae, Atherinidae, Gobiidae and Sparidae. Australian studies that have sampled saltmarsh creeks also have reported numerical dominance by estuarine species (Gibbs 1986, Morton et al. 1987, Davis 1988). Similar observations have been reported for saltmarsh flats and creeks in the northern hemisphere (Subrahmanyam \& Drake 1975, Shenker \& Dean 1979, Cattrijsse et al. 1994). For example, 2 of the 17 species found on an inundated marsh flat in Georgia represented $90 \%$ of the total abundance (Kneib \& Wagner 1994) and 2 species represented $79 \%$ of the abundance of larval fish in high marsh areas in New Jersey (Talbot \& Able 1984). Fourteen (61\%) of the 23 species found in the present study are of economic importance, which is comparable to the findings of studies done in creeks on Australian saltmarshes. Morton et al. (1987) found that $58 \%$ of all species caught in a saltmarsh creek in Moreton Bay (southeast Queensland) were of economic importance, and Gibbs (1986) found that $68 \%$ of species were economically important in a temperate saltmarsh creek in New South Wales.

On both marshes, fish assemblages differed between the 2 sampling periods. Since the first period was in winter, with sampling during the night, and the second period was in summer, with sampling during the day, differences could be the result of seasonal and/or diel patterns. Strong seasonal changes in fish assemblages have been shown for fish in subtidal creeks of saltmarshes (Morton et al. 1987), in deeper estuarine habitats in subtropical Queensland waters (Young \& Wadley 1979) and in marsh creeks in the USA (Rountree \& Able 1992). Diel differences in fish collections from saltmarsh creeks also have been shown in the USA (Rountree \& Able 1993). Both seasonal and diel patterns are therefore likely to be operating on the marshes sampled in the present study. The study was not aimed at separating the influence of these factors, and further surveys and experimental work would be needed to examine them fully.

In the present study, neither fish assemblages nor species richness differed between habitat types at any sampling period, and very few differences in fish den- 
sity were found between vegetated and unvegetated habitat. Even for the 2 species showing a significant difference in abundance between habitat types $(\mathrm{Mu}-$ gilogobius stigmaticus and Atherinomorus ogilbyi), the difference was not consistent across marshes or periods. The lack of difference in fish density between vegetated and unvegetated habitat is contrary to the results of studies done on marshes on the Gulf of Mexico coast of the USA. Greater overall abundances are associated with vegetation there, and many species are either more or less abundant in vegetation (Minello 1998, Rozas \& Zimmerman 2000). Those marshes, however, have a very different tidal regime compared to that of the marshes in subtropical Australia. There are no comparative results from the Atlantic coast of the USA, where tidal amplitudes are similar to those found in Queensland. The short periods of inundation of saltmarsh flats in southeast Queensland relative to those of northern hemisphere marshes would give fish little time to establish themselves in a preferred habitat. Furthermore, for fish to be in a particular habitat type at high tide (when sampling was done in the present study), they would in most cases need to pass through areas of the other habitat type. It is important to understand the influence of vegetation on the distribution of fish on subtropical Australian saltmarshes, because coastal managers are faced with the continued loss and degradation of marsh vegetation in southeast Queensland through human activities.

Fish densities were highly variable within habitat types. This might be due to the large spatial scale over which sampling was done, incorporating a high degree of habitat heterogeneity. Given that the patchy distribution of fish cannot be explained by the presence or absence of vegetation, future research should examine the importance of other habitat factors such as the proximity to mangroves and rivulets.

The use of pop nets in this study permitted extensive sampling at many randomly selected sites. Installation of pop nets, however, does disturb the marsh surface, and this could affect the accuracy of estimates of fish density. Vegetation is not obviously disturbed during setting up, so the method should not have biased the comparison of vegetated and unvegetated habitat. Since nets were moved daily, the concern about longterm effects on habitat of more permanent sampling gear is avoided (Loftus \& Eklund 1994). Disturbance to surface sediments may lead to over- or under-estimates of fish densities. Catches from pop nets should be compared with other netting techniques where possible in the future.

A higher proportion of juvenile Ambassis marianus was found in vegetated habitat than in unvegetated habitat at Meldale in winter. Zimmerman et al. (1984) also found a higher proportion of smaller size classes of
Farfantepenaeus aztecus in vegetated Spartina habitat, although a very small sample size was used to represent unvegetated habitat. Since other species have been found to have a higher vulnerability to predation in unvegetated habitat (Minello \& Zimmerman 1985, Rozas \& Odum 1988), this may explain the lower proportion of juveniles in unvegetated habitat in the present study, if juveniles of this species suffer higher predation rates than adults. Gobiopterus semivestitus, however, had a higher proportion of adults in vegetated habitat. It may be that juveniles of this species are less easily detected by predators in unvegetated habitat. Explanations involving predatory pressures on fish on the saltmarsh flats must await future examination of the diets of fish occurring on the marshes.

The present study sampled up to $413 \mathrm{~m}$ from the marsh edge onto marsh flats, and found estuarine (Gobiidae, e.g. Mugilogobius stigmaticus) and marine/ estuarine (Sparidae, e.g. Acanthopagrus australis) species at considerable distances onto the marsh. Previous studies that have sampled farther than the marsh edge have reported estuarine species to be the principal taxa occupying these areas, with marine species occurring infrequently away from the marsh edge (Talbot \& Able 1984, Rakocinski et al. 1992, Baltz et al. 1993, Kneib \& Wagner 1994, Peterson \& Turner 1994). It was suggested that the marine species Mugil cephalus ventures farther onto the marsh (e.g. $15 \mathrm{~m}$ ) in deeper, more frequently flooded marshes (Peterson \& Turner 1994). This was also shown for Mugil spp. and Leiostomus xanthurus on a saltmarsh in Georgia (Kneib 1991) and M. cephalus on a saltmarsh in Louisiana (Rozas 1992). The distances studied previously, however, are much less than in the present study. When comparing fish assemblages of Australian saltmarshes at similar distances to those sampled on North American saltmarshes, Australian saltmarshes appear to have a lower proportion of estuarine species as well as lower overall densities.

At Meldale in winter, water depth was positively related to species richness and the density of several fish species, in both vegetated and unvegetated habitats. Morton et al. (1987) found that water depth in a tidal inlet, which fed a saltmarsh flat in Moreton Bay, Queensland, was positively related to total fish abundance and species richness. More fish and higher numbers of species entered the saltmarsh creek on higher tides. This was attributed to a higher number of species and individuals being able to move in and take advantage of the larger area available on higher tides. It was also suggested that fish may have been swept into the tidal creek by stronger currents associated with higher tides (Morton et al. 1987). Zimmerman \& Minello (1984) found that the highest densities of Farfantepenaeus aztecus in vegetated marsh habitats coincided with 
seasonally high water levels. Hydrologic, topographic and geomorphic characteristics of a marsh may all contribute to the accessibility and utilisation of marshes by nekton, and greater water depths may facilitate such use of vegetated marshes for some species (Kneib 1994, Rozas 1995).

At Theodolite, similar numbers of fish occurred at most distances onto the marsh, whereas fewer fish were found farther onto the marsh at Meldale. The Theodolite marsh, however, is narrower than Meldale (201 vs $413 \mathrm{~m}$ ), and the first $200 \mathrm{~m}$ of the Meldale marsh actually had similar densities of fish at different distances (but higher overall densities than Theodolite). The pattern in density with distance onto the marsh seems to be one of consistent fish densities across the first $200 \mathrm{~m}$ or so of marsh, with reduced densities farther than $200 \mathrm{~m}$ onto the marsh. Additional evidence from other marshes is needed to determine whether a general pattern is operating. This study has shown that despite the relatively low duration and frequency of inundation, a number of fish species, including economically important species, consistently occurred on the marsh flats. Our findings also showed that fishes are patchily distributed, occur at relatively low densities, and move considerable distances across intertidal saltmarsh flats in subtropical Queensland.

Acknowledgements. This project was made possible by the assistance of several field volunteers, especially R. Duffy, B. Healey and R. Warne, and by the financial support of the Fisheries Research and Development Corporation. R. Thomas improved the manuscript, and J. Johnson of the Queensland Museum assisted with fish identifications. The ideas of A. Moussalli and R. Quinn helped initiate this work.

\section{LITERATURE CITED}

Adam P (1990) Saltmarsh ecology. Cambridge University Press, Cambridge

Baltz DM, Rakocinski C, Fleeger JW (1993) Microhabitat use by marsh-edge fishes in a Louisiana estuary. Environ Biol Fish 36:109-126

Boesch DE, Turner RE (1984) Dependence of fishery species on saltmarsh: the role of food and refuge. Estuaries 7: $460-468$

Cattrijsse A, Makwaia ES, Dankwa HR, Hamerlynck O, Hemminga MA (1994) Nekton communities of an intertidal creek of a European estuarine brackish marsh. Mar Ecol Prog Ser 109:195-208

Clarke KR (1993) Non-parametric multivariate analyses of changes in community structure. Aust J Ecol 18:117-143

Connolly RM (1994) Comparison of fish catches from a buoyant pop net and a beach seine net in a shallow seagrass habitat. Mar Ecol Prog Ser 109:305-309

Connolly RM (1999) Saltmarsh as habitat for fish and nektonic crustaceans: challenges in sampling designs and methods. Aust J Ecol 24(4):422-430

Connolly RM, Dalton A, Bass DA (1997) Fish use of an inun- dated saltmarsh flat in a temperate Australian estuary. Aust J Ecol 22:222-226

Davis TLO (1988) Temporal changes in the fish fauna entering a tidal swamp system in tropical Australia. Environ Biol Fish 21:161-172

Gibbs PJ (1986) The fauna and fishery of Wallis Lake. In: Wallis Lake: present and future. Australian Marine Science Association, Sydney, p 1-7

Kneib RT (1991) Flume weir for quantitative collection of nekton from vegetated intertidal habitats. Mar Ecol Prog Ser 75:29-38

Kneib RT (1994) Spatial pattern, spatial scale, and feeding in fishes. In: Stouder DJ, Fresh KL, Feller RJ (eds) Theory and application in fish feeding ecology. Belle W Baruch Library in Marine Science No. 18. University of South Carolina Press, Columbia, p 171-185

Kneib RT (1997) The role of tidal marshes in the ecology of estuarine nekton. Oceanogr Mar Biol Annu Rev 35: $163-220$

Kneib RT, Wagner SL (1994) Nekton use of vegetated marsh habitats at different stages of tidal inundation. Mar Ecol Prog Ser 106:227-238

Loftus WF, Eklund A (1994) Long-term dynamics of an Everglades small-fish assemblage. In: Davis SM, Ogden JC (eds) Everglades: the ecosystem and its restoration. St Lucie Press, Delray Beach, FL, p 461-483

Minello TJ (1998) Nekton densities in shallow estuarine habitats of Texas and Louisiana and the identification of essential fish habitat. Am Fish Soc Symp 22:43-75

Minello TJ, Zimmerman RJ (1985) Differential selection for vegetative structure between juvenile brown shrimp (Penaeus aztecus) and white shrimp (P. setiferus), and implications in predator-prey relationships. Estuar Coast Shelf Sci 20:707-716

Morton RM, Pollock BR, Beumer JP (1987) The occurrence and diet of fishes in a tidal inlet to a saltmarsh in southern Moreton Bay, Queensland. Aust J Ecol 12:217-237

Morton RM, Pollock BR, Beumer JP (1988) Fishes of a subtropical Australian saltmarsh and their predation upon mosquitoes. Environ Biol Fish 21:185-194

Peterson GW, Turner RE (1994) The value of salt marsh edge vs interior as a habitat for fish and decapod crustaceans in a Louisiana tidal marsh. Estuaries 17:235-262

Rakocinski CF, Baltz DM, Fleeger JW (1992) Correspondence between environmental gradients and the community structure of marsh-edge fishes in a Louisiana estuary. Mar Ecol Prog Ser 80:135-148

Rountree RA, Able KW (1992) Fauna of polyhaline subtidal marsh creeks in southern New Jersey: composition, abundance and biomass. Estuaries 15:171-185

Rountree RA, Able KW (1993) Diel variation in decapod crustacean and fish assemblages in New Jersey polyhaline marsh creeks. Estuar Coast Shelf Sci 37:181-201

Rozas LP (1992) Bottomless lift net for quantitatively sampling nekton on intertidal marshes. Mar Ecol Prog Ser 89: 287-292

Rozas LP (1995) Hydroperiod and its influence on nekton use of the salt marsh: a pulsing ecosystem. Estuaries 18: $579-590$

Rozas LP, Odum WE (1988) Occupation of submerged aquatic vegetation by fishes: testing the roles of food and refuge. Oecologia 77:101-106

Rozas LP, Reed DJ (1993) Nekton use of marsh-surface habitats in Louisiana (USA) deltaic salt marshes undergoing submergence. Mar Ecol Prog Ser 96:147-157

Rozas LP, Zimmerman RJ (2000) Small-scale patterns of nekton use among marsh and adjacent shallow nonvegetated 
areas of the Galveston Bay Estuary, Texas (USA). Mar Ecol Prog Ser 193:217-239

Shenker JM, Dean JM (1979) The utilization of an intertidal salt marsh creek by larval and juvenile fishes: abundance, diversity and temporal variation. Estuaries 2:154-163

Subrahmanyam CB, Drake SH (1975) Studies on the animal communities in two North Florida salt marshes. Bull Mar Sci 25:445-465

Talbot CW, Able KW (1984) Composition and distribution of larval fishes in New Jersey high marshes. Estuaries 7:434-443

Weinstein MP (1979) Shallow marsh habitats as primary nurseries for fishes and shellfish, Cape Fear River, North Car-

Editorial responsibility: Ron Kneib (Contributing Editor), Sapelo Island, Georgia, USA olina. Fish Bull US 77:339-357

Young PC, Wadley VA (1979) Distribution of shallow-water epibenthic macrofauna in Moreton Bay, Queensland, Australia. Mar Biol 53:83-97

Zar JH (1999) Biostatistical analysis, 4th edn. Prentice Hall, Englewood Cliffs, NJ

Zimmerman RJ, Minello TJ (1984) Densities of Penaeus aztecus, Penaeus setiferus, and other natant macrofauna in a Texas salt marsh. Estuaries 7:421-433

Zimmerman RJ, Minello TJ, Zamora G (1984) Selection of vegetated habitat by brown shrimp, Penaeus aztecus, in a Galveston Bay salt marsh. Fish Bull US 82:325-336

Submitted: July 26, 1999; Accepted: July 4, 2000

Proofs received from author(s): November 23, 2000 